\title{
Current Treatment Options Available for COVID-19 : A Review
}

\author{
Maulin Mehta ${ }^{1 *}$ and Jayant Patharkar ${ }^{2}$ \\ 'Associate Professor, Department of Pharmacology, Smt. B.K. Shah Medical Institute and Research Center, \\ Sumandeep Vidyapeeth, Deemed to be University, Piparia, Waghodia, Vadodara - 391760, \\ Gujarat, India; mdmmehta@gmail.com \\ ${ }^{2}$ Assistant Professor, Department of Pharmacology, Smt. B.K. Shah Medical Institute and Research Center, \\ Sumandeep Vidyapeeth, Deemed to be University, Piparia, Waghodia, Vadodara - 391760, Gujarat, India
}

\begin{abstract}
The World Health Organization (WHO) introduced the term 2019 novel corona virus to refer to a corona virus that affected the lower respiratory tract of patients with pneumonia in Wuhan, China. The official name of the 2019 novel corona virus is corona virus disease (COVID-19), announced by WHO. The total reported cases of COVID-19 as of $15^{\text {th }}$ June, 2020 are $79,95,877$ and 4,35,598 reported deaths. Non-availability of vaccines and medicines for its treatment is really threatening to the world right now. All chloroquine and Hydroxychloroquine, antibacterial therapy like azithromycin and doxycycline, antiviral therapy like lopinavir/ritonavir and remdesivir, convalescent plasma therapy, zinc, vaccines and Tocilizumab are part of possible management options and none is officially approved for the treatment. Current review of various articles by searching on PubMed is initiated with intention of creating meaningful information regarding all possible management that is available or will be available in near future of COVID-19.
\end{abstract}

Keywords: Convalescent Plasma Therapy, Corona-VIrus Disease (COVID)-19, Hydroxychloroquine, Remdesivir, Tocilizumab, Vaccine

\section{Introduction}

After an outbreak in Wuhan city in December 2019, there has been continuously increase in the flow of cases with Corona virus disease 2019 (COVID-19) globally. The World Health Organization (WHO) introduced the term 2019 novel corona virus to refer to a corona virus that affected the lower respiratory tract of patients with pneumonia in Wuhan, China. The official name of the 2019 novel corona virus is Corona Virus Disease (COVID-19), announced by WHO and the current reference name for the virus is Severe Acute Respiratory Syndrome Corona-Virus 2 (SARS-CoV-2) ${ }^{1-3}$. The total reported cases in India of COVID-19 as of $15^{\text {th }}$ June,2020 are $79,95,877$ and $4,35,598$ reported deaths ${ }^{4}$. The numbers itself depict the seriousness of the condition. There are different case fatality rates due to corona virus disease conditions occurred in $21^{\text {st }}$ century, vary from $2.5 \%$ (2019-nCoV), 10\% (SARS), to 35\% (MERS-CoV) ${ }^{5-7}$. COVID-19 is still creating a panic situation despite of lowest fatality rate among all. It is might be due to highly contagiousness of the disease. On over and above of this, non-availability of vaccines and medicines for its treatment is really threatening to the world right now. There are numbers of trials going on worldwide over possible cure of the disease, in terms of new vaccines and medicines for the treatment strategy. Current review of various articles is initiated with intention of generating information regarding all possible management that is available or will be available in near future of COVID-19.

${ }^{*}$ Author for correspondence 


\section{Methods}

All the data was retrieved with the help of search engine like PubMed and clinicaltrials.gov. Various search terms were used for retrieving authentic articles from PubMed. The used terms were like treatment of COVID-19, Chloroquine, azithromycin, lopinavir, ritonavir, convalescent plasma therapy, zinc, vaccines and tocilizumab. The Boolean term AND was used to find maximum articles related with treatment options for COVID-19 patients and their current status. After reviewing these articles, we were able to find out following results for current treatment options for COVID-19.

\section{Results}

Results include (Table 1)

Table 1. Various studied conducted on COVID-19

\begin{tabular}{|c|c|c|c|c|c|c|}
\hline $\begin{array}{l}\text { Sr. } \\
\text { No. }\end{array}$ & Authors & Year & $\begin{array}{l}\text { Type of } \\
\text { COVID-19 } \\
\text { patients }\end{array}$ & $\begin{array}{l}\text { Sample } \\
\text { Size }\end{array}$ & Medicine & Prognosis \\
\hline 1. & $\begin{array}{l}\text { Chen J, Liu D, Liu L, Liu P, Xu Q, } \\
\text { Xia L, et al. }\end{array}$ & 2020 & Mild & 30 & Hydroxy-chloroquine & Good \\
\hline 2. & $\begin{array}{l}\text { Gautret P, Lagier JC, Parola P, } \\
\text { Meddeb L, Mailhe M, Doudier } \\
\text { B, et al. }\end{array}$ & 2020 & Severe & 20 & $\begin{array}{l}\text { Azithromycin with } \\
\text { Hydroxy-chloroquine }\end{array}$ & Good \\
\hline 3. & $\begin{array}{l}\text { Molina JM, Delaugerre C, Le Goff } \\
\text { J, Mela-Lima B, Ponscarme D, } \\
\text { GoldwirtL, et al. }\end{array}$ & 2020 & Severe & 11 & $\begin{array}{l}\text { Azithromycin with } \\
\text { Hydroxy-chloroquine }\end{array}$ & Poor \\
\hline 4. & $\begin{array}{l}\text { Cao B, Wang Y, Wen D, Liu W, } \\
\text { Wang J, Fan G, et al. }\end{array}$ & 2020 & Severe & 199 & Lopinavir/ Ritonavir & Poor \\
\hline 5. & $\begin{array}{l}\text { Grein J, Ohmagari N, Shin D, } \\
\text { Diaz G, Asperges E, Castagna A, } \\
\text { et al. }\end{array}$ & 2020 & Mild & 53 & Remdesivir & Good \\
\hline 6. & $\begin{array}{l}\text { Shen C, Wang Z, Zhao F, Yang Y, } \\
\text { Li J, Yuan J, et al. }\end{array}$ & 2020 & Mild & 05 & $\begin{array}{l}\text { Convalescent Plasma } \\
\text { Therapy }\end{array}$ & Good \\
\hline 7. & $\begin{array}{l}\text { Xu X, Han M, Li T, Sun W, Wang } \\
\text { D, Fu B, et al. }\end{array}$ & 2020 & Mild & 20 & Tocilizumab & Good \\
\hline 8. & $\begin{array}{l}\text { Toniati P, Piva S, Cattalini M, } \\
\text { Garrafa E, Regola F, Castelli F, } \\
\text { et al. }\end{array}$ & 2020 & Mild & 100 & Tocilizumab & Good \\
\hline 9. & NA & 2020 & NA & NA & Vaccine & $\begin{array}{l}\text { Under } \\
\text { Clinical } \\
\text { evaluation }\end{array}$ \\
\hline
\end{tabular}


lupus erythematous. In vitro study on hydroxychloroquine reveals that it is more potent than chloroquine. In a study done by Estari Mamidala, et al., hydroxychloroquine with efficient docking score proven its anti-viral efficacy for management of COVID-19 patients by recommended dose for Hydroxychloroquine sulfate, in the treatment of COVID-19 patients, is $400 \mathrm{mg}$ given twice daily for 1 day followed by $200 \mathrm{mg}$ twice daily for another 4 days ${ }^{12}$. One of the completed pilot study on 30 patients in china concluded that prognosis is better with use of hydroxychloroquine ${ }^{13}$. Other 29 clinical trials related with hydroxychloroquine therapy are under phase II as per information available on clinicaltrials.gov on $23^{\text {rd }}$ April 2020. Results of these trials are very important in considering chloroquine as one of the major option for treatment of COVID-19. In one of the case reported in Brazil, the patient with acute respiratory distress syndrome due to COVID-19 presented with a rapid increase in transaminases after the introduction of Hydroxychloroquine, followed by a rapid reduction after the drug was discontinued ${ }^{14}$. It is possible that such adverse event of hydroxychloroquine might get exaggerated in COVID-19 patients. Such serious adverse event related with Hydroxychloroquine should be look out. Hydroxycholoroquine should be excluded from the treatment regimen in COVID-19 patients with comorbidity of liver dysfunction.

\subsection{Antibacterial Therapy}

Mechanism: CD147 is also the receptor on host cells which allow invasion of SARS-CoV ${ }^{15}$. Azithromycin blocks invasion through CD147 by blocking it. It is one of the possible content of drug regimen for the treatment of COVID-19. By blocking CD147, enhancing the effect of hydroxychloroquine is best possible mechanism for use of azithromycin in COVID-19.

In one study, azithromycin (in dose of $500 \mathrm{mg}$ on day 1 , followed by $250 \mathrm{mg}$ per day up to day 5) was shown to significantly increase the efficacy of hydroxychloroquine (200 mg three times per day for 10 days) in the treatment of 20 severe COVID-19 patients ${ }^{16}$. Currently there are 11 clinical trials going on under phase 2 of development. In most of the trials, efficacy of combination (Hydroxychloro quine+Azithromycin) is going to be compared with others. Similar combination was given to 11 patients in France and the outcome was not good in that case. In this study done in France, one patient discontinued the treatment due to QT interval prolongation, one died and two were transferred to
$\mathrm{ICU}^{17}$. Both the studies have contradictory results, but both were done on very small number of patients. In French study, Comorbid severe conditions of patients could be the reason of failure of such combination. As we know, both of the drugs having mechanism of blocking invasion of virus inside the host cells, it is very important that we give drug early during course of disease to obtain best outcome.

Some of the authors have also written about doxycycline as possible treatment of COVID-19 because of its possible anti-inflammatory action against IL- $6^{18,19}$. Currently no single clinical trial is going on to check the efficacy of doxycycline in COVID-19 infection.

\subsection{Antiviral Therapy}

Mechanism: As protease inhibitor, acts by inhibiting formation of various functional proteins from large viral polyprotein synthesized in infected host cells. Some drugs act as nucleoside analogue, lead to nucleotide synthesis inhibition and chain termination of viral genome.

Lopinavir/ritonavir, protease inhibitor, combination is useful in HIV infection ${ }^{11}$. Its usefulness is also checked in clinical trials for one of the possible treatment option of COVID-19 infection. In the randomized clinical trial done by Cao et al., use of lopinavir/ritonavir (400 mg/100 $\mathrm{mg}$, twice-daily for 14 days) in the treatment of COVID19 in patients with COVID-19 did not show any beneficial effect compared with standard care group ${ }^{20}$. There are more 9 clinical trials are going on to check the efficacy of lopinavir/ritonavir combination. Most of the trials are about comparing their efficacy with hydroxychloroquine in the chemoprophylaxis and treatment of COVID-19. We have to wait for the result of these trials.

One more antiviral drug is remdesivir, nucleoside analogue. One animal study conducted by de wit $\mathrm{E}$, et al., suggested the usefulness of remdesivir in MERS-CoV infection ${ }^{21}$. Currently there are 6 clinical trials going on, out of which, two trials in china were suspended due to less availability of patients in Beijing and Wuhan, China ${ }^{22}$. In one of the study by Jonathan grain, total 36 out of 53 (68\%) patients have shown clinical improvement after remdesivir therapy ${ }^{23}$.

\subsection{Convalescent Plasma Therapy}

Mechanism: Antibodies present in plasma of recovered patients from COVID-19, will suppress viral load in COVID-19 patients. 
It is proven effective in previous SARS/MERS infections in various countries worldwide ${ }^{24}$. In current COVID-19 situation, one case series of 5 COVID19 patients, conducted by Shenzhen et al., concluded improvement in their clinical status after giving plasma therapy. Small sample size is limitation of this study ${ }^{25}$. This result is encouraging for doing further studies on Convalescent Plasma therapy and includes it as major treatment option. Total 19 clinical trials are going on all over the world. In India, ICMR also invited a letter of intent from various institutions to participate in clinical trial to study the efficacy and safety of plasma therapy in COVID-19 patients. So it is not recommended so far as treatment option outside of clinical trials in India ${ }^{26}$.

\subsection{Zinc}

Mechanism: Zinc is very important for antiviral immunity by producing cytokine and improving $\mathrm{T}$ lymphocyte functions.

Zinc can be used as dietary supplements to boost the human immunity. It can be added in combination with other treatment against COVID-19.

\subsection{Vaccine}

Other than medicines, vaccine is also hope for billions in the worldwide to survive the fight against COVID19 infection. Many countries in the world are currently working on making effective vaccines against COVID-19. Out of these, 5 candidate vaccines are in clinical evaluation, while 71 vaccines are in preclinical evaluation ${ }^{27}$. First outcome of vaccine trial will take at least one year from now, whether it will be success or loss.

\subsection{Tocilizumab}

Mechanism: IL-6 receptor antagonist and by that way it blocks inflammatory storm that is generated in COVID19 patietns ${ }^{28}$.

It is proven effective as anti-inflammatory drug in patients of rheumatoid arthritis ${ }^{29}$. It is also proven effective in small pilot study done on 20 patients of COVID-19 in China $^{30}$. In another study done in Italy on 100 COVID19 patients by Paola toniati et al. mentioned that at end of 10 days after receiving Tocilizumab, total 77 patients improved or stabilized. Timely identification of the hyperinflammatory state and its treatment may be crucial in management of COVID-19 patients by Tocilizumab ${ }^{31}$.
Currently there are total 55 trials on Tocilizumab effectiveness in COVID-19 patients going on worldwide. Out of these, study entitled "The use of Tocilizumab in the Management of Patients who have Severe COVID-19 with Suspected Pulmonary Hyperinflammation" conducted in Israel has reached Phase IV as information available on 15 th June $2020^{32}$. It is still very early to say about its $100 \%$ effectiveness in treatment of COVID-19 patients.

\section{Revised Guidelines on Clinical Management of COVID-19 by Ministry of Health and Family Welfare (MOHFW) in India}

Under the sub-heading of management of COVID-19: Patients divided into three categories, overall symptomatic treatment, following drugs is standard operating procedure:

- Mild cases:

○ Isolation ${ }^{33}$

- Moderate cases: $(\mathrm{RR}>24 / \mathrm{min}$ or $\mathrm{SpO} 2<94 \%$ at room air)

○ Tab Hydroxychloroquine

Dose: $400 \mathrm{mg}$ twice in a day for day 1 followed by $200 \mathrm{mg}$ twice in a day for 4 days (only after ECG assessment)

○ Consider IV methylprednisolone

Dose: 0.5 to $1 \mathrm{mg} / \mathrm{kg}$ for 3 days (preferably within 48 hours of admission/oxygen requirement is increasing/ inflammatory markers are increased)

o Prophylactic dose of Unfractionated Heparin or Low molecular weight heparin (e.g., enoxaparin 40 mg per day SC)

${ }^{*}$ Antibiotics should not be prescribed on regular basis unless there is bacterial infection ${ }^{33}$

- Severe cases:

○ Management of associated condition, e.g. ARDS and/or Septic shock

Under the sub-heading of investigational therapies, it is mentioned that following drugs should be used in a particular subgroup of patients:

i. Remdesivir (under Emergency Use Authorization): Patients with moderate disease (those on oxygen) with no contraindications:

- AST/ALT > 5 times Upper Limit of Normal (ULN) 
- Severe renal impairment (i.e., eGFR $<30 \mathrm{ml} / \mathrm{min} / \mathrm{m}^{2}$ or patients need for hemodialysis)

- Pregnancy or lactating females

- Children (those of $<12$ years of age)

Dose: $200 \mathrm{mg}$ IV on first day followed by $100 \mathrm{mg}$ IV every day for total 5 days

i. Convalescent plasma (Off Label): patients with moderate disease who are not improving or oxygen demand increases, with use of steroids.

Special conditions before giving convalescent plasma include:

- ABO compatibility and cross matching of the donor plasma

- Neutralizing titer of donor plasma, above the specific threshold (if the latter is not available, plasma IgG titer, above 1:640 should be used)

- Recipient monitored for several hours post transfusion for any transfusion reactions

- Contraindicated in patients with IgA deficiency or immunoglobulin allergy

Dose: In the range, e.g. from 4 to $13 \mathrm{ml} / \mathrm{kg}(200 \mathrm{ml}$ single dose, slowly over more than 2 hours)

i. Tocilizumab (Off Label): patients with moderate disease and increasing oxygen demand and in mechanically ventilated with use of steroids. Long term safety data is still not available for using in COVID 19 patients. Special precautions include:

- Raised inflammatory markers (e.g., CRP, Ferritin, IL-6)

- Careful monitoring required post Tocilizumab for secondary infections and neutropenia

- In active infections and Tuberculosis, should not be used.

Dose: $8 \mathrm{mg} / \mathrm{kg}$ (maximum $800 \mathrm{mg}$ at one time) slowly in $100 \mathrm{ml} \mathrm{NS}$ over 1 hour, repeated once after 12 to 24 hours if needed ${ }^{33}$

(Revised on $13^{\text {th }}$ June, 2020)

\section{Conclusion}

Use of drugs like hydroxychloroquine has given good prognosis in COVID-19 patients but due to its cardiac side effects, especially after its combination with azithromycin, one should remain vigilant about. Antiviral therapy remdesivir is showing quite promising result in one of study done on few COVID-19 patients. Convalescent plasma therapy is also showing good outcome but its use only limited in institutes enrolled under ICMR clinical trial. Zinc and other nutritional substances are very important for improving human immunity against virus. Tocilizumab can be proven effective in COVID-19 end stage patients with severe pulmonary hyper inflammation. Development of vaccines against COVID-19 will take long time. Until we come out with availability of proper management and vaccine for COVID-19, it is important to follow proper hand sanitization and social distancing norms by everyone worldwide to stay healthy.

\section{References}

1. Adhikari SP, Meng S, Wu YJ, Mao YP, Ye RX, Wang QZ, et al. Epidemiology, causes, clinical manifestation and diagnosis, prevention and control of corona virus disease (COVID-19) during the early outbreak period: A scoping review. Infectious diseases of poverty. 2020 Dec; 9(1):12. https://doi.org/10.1186/s40249-020-00646-x. PMid: 32183901, PMCid: PMC7079521.

2. CDC.2019 Novel Corona virus, Wuhan, China; 2020. Accessed on 23/04/2020. https://www.cdc.gov/coronavirus/2019nCoV/summary.html.

3. WHO. Novel Corona virus China; 2020. Accessed on 23/04/2020/. https:/www.who.int/csr/don/12-january2020-novel-coronavirus-china/en/.

4. https://www.worldometers.info/coronavirus/. Accessed on 15/06/2020.

5. Sarma P, Prajapat M, Avti P, Kaur H, Kumar S, Medhi B. Therapeutic options for the treatment of 2019-novel corona virus: An evidence-based approach. Indian Journal of Pharmacology. 2020 Jan; 52(1):1. https://doi.org/10.4103/ ijp.IJP_119_20. PMid: 32201439, PMCid: PMC7074432.

6. Battegay M, Kuehl R, Tschudin-Sutter S, Hirsch $\mathrm{HH}$, Widmer AF, Neher RA. 2019-novel Corona virus (2019$\mathrm{nCoV})$ : Estimating the case fatality rate-a word of caution. Swiss Medical Weekly. 2020 Feb 7; 150(0506). https://doi. org/10.4414/smw.2020.20203.

7. Zumla A, Chan JF, Azhar EI, Hui DS, Yuen KY. Coronaviruses-drug discovery and therapeutic options. Nature Reviews Drug Discovery. 2016 May; 15(5):327-47. https://doi.org/10.1038/nrd.2015.37. PMid: 26868298, PMCid: PMC7097181.

8. Li L, Li R, Wu Z, Yang X, Zhao M, Liu J, et al. Therapeutic strategies for critically ill patients with COVID-19. Annals of Intensive Care. 2020 Dec; 10:1-9. https://doi. org/10.1186/s13613-020-00661-z. PMid: 32307593, PMCid: PMC7167303. 
9. Dimitrov DS. The secret life of ACE2 as a receptor for the SARS virus. Cell. 2003 Dec 12; 115(6):652-53. https://doi. org/10.1016/S0092-8674(03)00976-0.

10. Wang M, Cao R, Zhang L, Yang X, Liu J, Xu M, et al. Remdesivir and chloroquine effectively inhibit the recently emerged novel corona virus $(2019-\mathrm{nCoV})$ in vitro. Cell research. 2020 Mar; 30(3):269-71. https://doi.org/10.1038/ s41422-020-0282-0. PMid: 32020029, PMCid: PMC7054408.

11. Mamidala E, Davella R, Gurrapu S. An InSilico Approach for Identification of Inhibitors as a Potential Therapeutics Targeting SARS-Cov-2 Protease. Asian Journal of Pharmaceutical Research and Health Care. 2020; 12(1):3-9.

12. Yao X, Ye F, Zhang M, Cui C, Huang B, Niu P, et al. In vitro antiviral activity and projection of optimized dosing design of hydroxychloroquine for the treatment of severe acute respiratory syndrome corona virus 2 (SARS-CoV-2). Clinical Infectious Diseases. 2020 Mar 9. https://doi.org/10.1093/cid/ ciaa237. PMid: 32150618, PMCid: PMC7108130.

13. Chen J, Liu D, Liu L, Liu P, Xu Q, Xia L, et al. A pilot study of hydroxychloroquine in treatment of patients with common corona virus disease-19 (COVID-19). Journal of Zhejiang University (Medical Science). 2020 May 25; 49(2):215-19. Accessed on 23/04/2020. https://doi.org/10.3785/j.issn.10089292.2020.03.03 https://clinicaltrials.gov/ct2/show/study/ NCT04261517.

14. Falcão MB, de Góes Cavalcanti LP, Filgueiras Filho NM, de Brito CA. Case Report: Hepatotoxicity associated with the use of Hydroxychloroquine in a Patient with COVID-19. The American Journal of Tropical Medicine and Hygiene. 2020 Jun 3; 102(6):1214-16. https://doi.org/10.4269/ajtmh.200276. PMid: 32314698, PMCid: PMC7253107.

15. Wang K, Chen W, Zhou YS, Lian JQ, Zhang Z, Du P, et al. SARS-CoV-2 invades host cells via a novel route: CD147-spike protein. Bio. Rxiv. 2020 Jan 1. https://doi. org/10.1101/2020.03.14.988345

16. Gautret P, Lagier JC, Parola P, Meddeb L, Mailhe M, Doudier B, et al. Hydroxychloroquine and azithromycin as a treatment of COVID-19: Results of an openlabel non-randomized clinical trial. International Journal of Antimicrobial Agents. 2020 Mar 20; 105949. https://doi.org/10.1016/j.ijantimicag.2020.105949. PMid: 32205204, PMCid: PMC7102549.

17. Molina JM, Delaugerre C, Le Goff J, Mela-Lima B, Ponscarme D, Goldwirt L, et al. No evidence of rapid antiviral clearance or clinical benefit with the combination of hydroxychloroquine and azithromycin in patients with severe COVID-19 infection. Med. Mal. Infect. 2020 Mar 30; 50(384):30085-88. https://doi.org/10.1016/j.medmal.2020.03.006, https://www. sciencedirect.com/science/article/pii/S0399077X20300858. PMid: 32240719, PMCid: PMC7195369.
18. Conforti C, Giuffrida R, Zalaudek I, Di Meo N. Doxycycline, a widely used antibiotic in dermatology with a possible antiinflammatory action against IL-6 in COVID-19 outbreak. Dermatologic Therapy. 2020 Jan 1. https://doi.org/10.1111/ dth.13437.

19. Di Caprio R, Lembo S, Di Costanzo L, Balato A, Monfrecola G. Anti-inflammatory properties of low and high doxycycline doses: an in vitro study. Mediators of Inflammation. 2015 Jan 1; 2015. https://doi.org/10.1155/2015/329418. PMid: 25977597, PMCid: PMC4421036.

20. Cao B, Wang Y, Wen D, Liu W, Wang J, Fan G, et al. A trial of lopinavir-ritonavir in adults hospitalized with severe Covid19. New England Journal of Medicine. 2020 Mar 18. https:// doi.org/10.1056/NEJMo a2001282.

21. de Wit E, Feldmann F, Cronin J, Jordan R, Okumura A, Thomas T, et al. Prophylactic and therapeutic remdesivir (GS-5734) treatment in the rhesus macaque model of MERS-CoV infection. Proceedings of the National Academy of Sciences. 2020 Mar 24; 117(12):6771-76. https://doi. org/10.1073/pnas.1922083117. PMid: 32054787, PMCid: PMC7104368.

22. Remdesivir in COVID-19. Accessed on 27/04/2020. https:// clinicaltrials.gov.

23. Grein J, Ohmagari N, Shin D, Diaz G, Asperges E, Castagna $A$, et al. Compassionate use of remdesivir for patients with severe Covid-19. New England Journal of Medicine. 2020 Jun 11; 382(24):2327-36. https://doi.org/10.1056/ NEJMoa2007016. PMid: 32275812, PMCid: PMC7169476.

24. Alzoughool F, Alanagreh LA. Corona virus drugs: Using plasma from recovered patients as a treatment for COVID19. International Journal of Risk and Safety in Medicine. 2020 Apr 13(Preprint); 1-5. https://doi.org/10.3233/JRS201017. PMid: 32310190, PMCid: PMC7306893.

25. Shen C, Wang Z, Zhao F, Yang Y, Li J, Yuan J, et al. Treatment of 5 critically ill patients with COVID-19 with convalescent plasma. Jama. 2020 Apr 28; 323(16):1582-89. https://doi. org/10.1001/jama.2020.4783. PMid: 32219428, PMCid: PMC7101507.

26. https:/icmr.nic.in/sites/default/files/upload_documents/ LOI_TPE_12042020.pdf. Accessed on 27/04/2020.

27. https://www.who.int/blueprint/priority-diseases/keyaction/novel-coronavirus-landscape-ncov.pdf. Accessed on 27/04/2020.

28. Fu B, Xu X, Wei $\mathrm{H}$. Why tocilizumab could be an effective treatment for severe COVID-19? Journal of Translational Medicine. 2020 Dec; 18(1):1-5. https://doi.org/10.1186/ s12967-020-02339-3. PMid: 32290839, PMCid: PMC7154566.

29. Biggioggero M, Crotti C, Becciolini A, Favalli EG. Tocilizumab in the treatment of rheumatoid arthritis: an evidence-based review and patient selection. Drug Design, 
Development and Therapy. 2019; 13:57. doi: 10.2147/ DDDT.S150580. https://doi.org/10.2147/DDDT.S150580. PMid:30587928, PMCid: PMC6304084.

30. Xu X, Han M, Li T, Sun W, Wang D, Fu B, et al. Effective treatment of severe COVID-19 patients with tocilizumab. Proceedings of the National Academy of Sciences. 2020 May 19; 117(20):10970-75. https://doi.org/10.1073/pnas.2005615117. PMid: 32350134, PMCid: PMC7245089.

31. Toniati P, Piva S, Cattalini M, Garrafa E, Regola F, Castelli F, et al. Tocilizumab for the treatment of severe COVID19 pneumonia with hyperinflammatory syndrome and acute respiratory failure: A single center study of 100 patients in Brescia, Italy. Autoimmunity Reviews. 2020 May; 19(7):102568. https://doi.org/10.1016/j.autrev.2020.102568. PMid: 32376398, PMCid: PMC7252115.

32. The use of Tocilizumab in the Management of Patients who have Severe COVID-19 with Suspected Pulmonary Hyperinflammation. Accessed on 15/06/2020. https:// clinicaltrials.gov/ct2/results?cond=\&term $=$ NCT04377750.

33. Revised guidelines on clinical management of COVID19 as on 13th June 2020. Accessed on 15/06/2020. https://www.mohfw.gov.in/pdf/ClinicalManage mentProtocolforCOVID19.pdf. 